\title{
American road narratives: reimagining mobility in literature and film
}

\section{Shaun Huston}

To cite this article: Shaun Huston (2016): American road narratives: reimagining mobility in literature and film, Social \& Cultural Geography, DOI: 10.1080/14649365.2015.1127555

To link to this article: http://dx.doi.org/10.1080/14649365.2015.1127555

Published online: 07 Jan 2016.

Submit your article to this journal $\sqsubset$

a)

View related articles $\asymp$

View Crossmark data $\complement \pi$ 
BOOK REVIEW

\section{American road narratives: reimagining mobility in literature and film,}

edited by Ann Brigham, Charlottesville and London, University of Virginia Press, 2015, $x+262$ pp., US\$29.50 (paperback), ISBN 978-0-8139-3750-2, US\$65.00 (cloth), ISBN 978-0-8139-3724-3

As Ann Brigham notes in the introduction to her book, the road, as a subject of myth in America, is typically assumed to mean 'freedom, rebellion or reinvention; there exists the promise of escape' (p. 4). Brigham, however, offers an alternate interpretation of this narrative, one where the road, and the mobility it represents, stands not for endless freedom but for a particular type of engagement with space, place and society. 'Incorporation', not escape, becomes the major theme.

The chapters of American Road Narratives are organized chronologically, covering the 1910 s to the early 2000s. The book also includes an epilogue that brings the analysis into 2013. Each chapter focuses on a particular set of texts, primarily books in the earlier part of the twentieth century and then also films in the latter part and beginning of the twenty-first. The selected texts, which include Sinclair Lewis' Free Air (1919), John A. Williams' This is My Country Too (1964), Thelma \& Louise (1991, dir. Ridley Scott), Smoke Signals (1998, dir. Chris Eyre), and Cormac McCarthy's The Road (2006), feature protagonists whose identities represent different outlooks and opportunities for travel and incorporation.

Brigham emphasizes how the road functions differently for different people on the basis of sex and gender, race and class, as well as on the basis of historical-geographic change, both in relation to character identities and how the problem of incorporation has been culturally framed at different times. For example, in the early part of the twentieth century, overcoming 'sectionalism' was a major political and cultural theme for many Americans, and the texts that Brigham selects here, Free Air and Thomas Wilby's and Agnes Wilby's On The Trail to Sunset (1912), address intersections of class, race and region. By contrast, in the late twentieth century, the politics of representation were at the fore of attempts to define the boundaries of incorporation into America as a historically constructed place and ideal. Brigham addresses this theme through Smoke Signals and David Seals' The Powwow Highway (1979), both of which feature Native subjects who 'agitate' American space and stories by drawing attention to the persistence and modernity of Native peoples and by raising questions about the nature of 'progress'. Brigham's emphasis on difference and change, in and of itself, challenges assumptions about the universality of the road as a space of freedom. More particularly, her reorienting of road narratives from escape to incorporation rests on two other theoretical concepts: mobility and scale.

Brigham emphasizes the changing and changeable meanings of mobility, at once at the heart of American identity - the freedom of the road, 'a nation of immigrants' - and also 'unsettling' for the way that becoming mobile can be disruptive of 'home' and the 'homeland'. This is underscored when the mobile subjects are of marginalized identities, as with 
women attempting to escape the home, or cultural 'outsiders', like immigrants and people of color, navigating places and spaces of white privilege. Most notably, accessing the mobility afforded by the automobile and the road not only connects people to places, but works to construct spaces and places at different scales. The act of travel gives material expression to discourses that construct and position spaces and places at different geographic scales, from the body to the world. The protagonists in the texts examined in American Road Narratives, through their travels, simultaneously make and also engage with the larger entities into which they either become or seek to be incorporated, whether successfully or not.

American Road Narratives references post-9/11 debates over mobility to introduce and frame the theme of incorporation. On the one hand, American reactions to 9/11 see mobility as a problem of foreign bodies entering the nation. On the other hand, the road trip, travel 'at home', became part of a social and cultural 'process of reclamation' (p. 189). This tension not only demonstrates the polysemic nature of mobility, but in turning 'the road' into a site of belonging and comfort rather than escape and rebellion, this tension also shows that the meanings of mobility, of the road and the car, are subject to changes in the historical and social contexts for their articulation. Brigham's book is a thoughtful and well-research reconsideration of these recurring themes in American history, geography and mythology.

Shaun Huston Department of Geography and Program in Film Studies, Western Oregon University, Monmouth, OR, USA Qhustons@wou.edu

() 2016 Shaun Huston http://dx.doi.org/10.1080/14649365.2015.1127555 